\title{
Social responsibility in the textile industry in Romania
}

DOI: 10.35530/IT.071.04.1676

NICOLETA ANDREEA NEACŞU

SIMONA BĂLĂŞESCU

MARIUS BĂLĂŞESCU

CARMEN ELENA ANTON

\section{ABSTRACT - REZUMAT}

\section{Social responsibility in the textile industry in Romania}

In a sustainable society, the integration into the activity of entities of the actions from the sphere of social responsibility becomes more and more evident.

The study analyzes the textile industry in Romania in terms of social responsibility, the involvement of companies in this industry in asserting the values of this level. Thus, a quantitative marketing research is carried out at the level of the population in Romania, a piece of research which is aimed at identifying the opinions and attitudes of the citizens regarding the social responsibility adopted by the Romanian companies, with emphasis on the companies in the textile industry. In this research, particular attention was given to the comprehension of the reality of the aspects in which consumers perceive the requirements of social responsibility and of the way in which they function in practice. The results of this research can be used by the companies in the textile industry as well as by all the companies interested in this aspect in order to improve the quality of the services and of their implications in the social life and in order to respond to the needs of the citizens as well as possible.

Keywords: social responsibility, social ethics, consumer behaviour, quantitative research, textile industry

\section{Responsabilitatea socială în industria textilă din România}

Într-o societate sustenabilă, integrarea în activitatea entităţilor a acţiunilor din sfera responsabilităţii sociale se manifestă din ce în ce mai pregnant.

Studiul analizează industria textilă din România prin prisma responsabilității sociale, a implicării companiilor din această industrie în afirmarea valorilor pe acest palier. Astfel, se realizează o cercetare cantitativă de marketing la nivelul populației din România, cercetare care vizează cunoaşterea opiniilor și atitudinilor cetățenilor în legătură cu responsabilitatea socială adoptată de către companiile românești, cu accent pe companiile producătoare din industria textilă. În cadrul acestei cercetări o atenție deosebită s-a acordat cunoaşterii realității aspectelor în care consumatorii percep cerințele responsabilității sociale şi a modului în care acestea se manifestă în practică. Rezultatele acestei cercetări vor putea fi folosite de către companiile din industria textilă, dar și de către toate companiile interesate în acest sens, în vederea îmbunătățiii calității serviciilor oferite şi a implicării în viața socială şi pentru a răspunde cât mai bine nevoilor cetățenilor.

Cuvinte-cheie: responsabilitate socială, etică socială, comportamentul consumatorului, cercetare cantitativă, industria textilă

\section{INTRODUCTION}

The domain of textile industry is very well developed in Romania. Romania's overall international trade in 2015 was over 117.56 billion euro, $5.9 \%$ more over 2014, according to the data provided by the Ministry of Economy. The export of textiles, leather and footwear exceeds 5 billion euro, which represents $11 \%$ of Romania's overall exports and it has over 250,000 employees. There are over 9700 companies operating in these sectors. In Romania this has been a traditional sector for more than 120 years, but it is also very innovative and creative. Highly qualified people work in the field of both design and technology. In the top 100 companies with $100 \%$ Romanian capital, there are 41 companies from the domain of textile industry [1].

The affirmation of social responsibility is outlined in the circumstances of the contemporary society as a requirement, as an ever growing necessity. In the day-to-day reality, the manifestation of the requirements of the components that form social responsibility has become an ethical and legal obligation for the commercial societies, imposed by the general interests of the community. When companies comply with and integrate these requirements into their business, they are perceived by the community as socially responsible companies.

Internationally, there are concerns to ensure a balance between moral and the personal interest of companies. The economic growth of a company does not involve only making profit, but also its reinvestment. CSR strategic approach represents a prerequisite for achieving business success [2].

Corporate social responsibility (CSR) is perceived as a new form of cooperation between governments, business and civil society, and the promotion of social objectives by companies has got economic implications (for business, by their increased power within 
the community), political (for governments, by increasing the control on companies, although not always directly) and social (for the various stakeholder groups). The ethical behaviour of a commercial company has as coordinates the trust- and respect-based relationships with its trading partners.

The novelty of the information presented in this paper consists of the approach of social responsibility from the point of view of the consumer, his/ her perception of the social responsibility in the context of the sustainable development of the society.

The study carried out by CSRMedia and Valoria Business Solution explores the perceptions of CSR managers and specialists from various companies in Romania in terms of the evolution, dynamics and challenges of this field in 2017 and 2018. The results show that in Romania the companies' involvement in this field has increased from $27 \%$ in 2017, to $35 \%$ in 2018 [3]. By comparing it to our research on the views of the Romanian citizens on CSR, it has been found out that this concept is less known among consumers. This aspect requires a more active involvement of companies in CSR actions and better information and promotion of the initiatives.

\section{SOCIAL RESPONSIBILITY IN THE LITERATURE}

Corporate Social Responsibility (CSR) stands for the duty of companies to create a positive impact on society by the measures they adopt. Internationally, there are several types of CSR. According to the World Business Council for Sustainable Development, social responsibility is "a continuous commitment in the field of business, towards some ethical behaviour and towards its contribution to the economic development, along with an increase in the quality of life of the staff and their families, as well as for the local community and society as a whole" [4]. The European Commission defines corporate social responsibility as "a concept by which companies integrate social and environmental concerns into their commercial activities and interactions with other stakeholders, on a voluntary basis" [5]. The European Forum on corporate social responsibility in Europe, set up at the initiative of the European Commission, defines CSR as a concept by which companies integrate, voluntarily, social and ecological aspects in their business operations and in their interactions with their stakeholders [6]. Kotler and Lee have identified several types of corporate social responsibility practices that have worked over time and that have produced remarkable results at the organization level [7]. CSR is complementary to specific approaches in order to deliver enhanced social and environmental performance and it should not be understood as a legal substitute or as a task for the companies with public responsibilities, which mainly remain in the hands of governments [8-10].

The basic premise behind the CSR is that the profits, the people and the environment can be harmonized in a strategic corporate approach, so that the company becomes economically sustainable, socially responsible and attentive to environmental issues. It is considered that the integration of the aspects related to social responsibility by businesses in the adopted decisions and strategies brings along more benefits: reducing the costs associated to energy consumption and resources by implementing some ecological actions, by increasing the loyalty of employees and organizational citizenship behaviour by initiating programs for human resources development, by improving relations with governmental institutions [11-12].

Significant differences in CSR approach appear in the literature, where the authors have slightly differently perceived the responsibilities of a company to the society as a whole. Thus, the main debate in this area refers to two distinct concepts: CSR perceived as a moral obligation or duty towards a wider or narrower range of interest groups and the CSR as a voluntarily assumed initiative by companies to achieve social, but also economic objectives.

\section{RESEARCH METHODOLOGY}

In order to identify the attitude of the Romanian consumers regarding the social responsibility in the textile industry, a quantitative marketing research based on a sample of 428 respondents residing in Romania was carried out.

The main objective of the paper was to know the opinions and attitudes of the Romanian citizens in relation to the social responsibility adopted by the companies operating in Romania, with emphasis on the companies operating in the textile industry. Bearing in mind the topic of the paper, the research was based on several hypotheses, including:

- HO: At least $50 \%$ of Romanians are to a little extend familiar with CSR;

$\mathrm{H} 1$ : Less than $50 \%$ of Romanians are to a little extend familiar with CSR.

- H0: At most $50 \%$ of Romanians are satisfied with CSR actions organized by companies;

$\mathrm{H} 1$ : More than $50 \%$ of Romanians are satisfied with CSR actions organized by companies.

In this paper, the sampling method being non-aleatory, volunteer sampling of the respondents was carried out on the basis of a survey. For the collection the data, the survey method was used in the electronic format. The questionnaire (containing 20 questions) was designed on the Google Forms platform and it was distributed to Facebook groups with over 1500 members. Similarly, it has been distributed by means of the Instant Messaging application, Whatsapp. Being distributed online, the questionnaire collected 428 respondents, the researcher having no control over who answers it.

After having collected the information with the help of the questionnaire, the statistical data processing was done with the SSSP (Social Sciences Statistics Package) system. The first step was to define the relevant variables of the research. Afterwards, the response options were encoded in order to facilitate data computerization. The encoding was done 
according to each question and to the scale used for this question. The SSSP database was completed after all questionnaires were introduced and, in the end, the data were centralized as tables and graphs of frequency [13].

\section{RESEARCH RESULTS}

Although the practices of responsibility rendering in the Romanian corporate area have emerged as an import of values and principles taken from the European context, the indigenous companies have begun to assimilate and adapt them to the specificity of the organizational culture in Romania. Over the last three years we there has been a growing visibility of the CSR programs and there has been a large number of NGOs that promote on behalf of companies and with their financial aid various social causes [14]. In this context, it has become imperiously necessary to carry out research to provide an overview of the opinions of the Romanian citizens on the actions of companies in the sphere of social responsibility. The research has revealed a lot of information, the most relevant for the issues under consideration being presented below.

To the question referring to the understanding of the concept of "corporate social responsibility" (CSR), it is noticeable that $40.2 \%$ of the respondents know little about this concept, but a very close percentage of $30.7 \%$ know and understand to a great extent what CSR presupposes. Similarly, it is noted that $10.3 \%$ of the respondents know to some extent what CSR presupposes. The percentage of the people who do not know this concept at all is significant (19.6\%) (table 1 and figure 1).

Table 1

\begin{tabular}{|l|c|c|c|c|}
\hline \multicolumn{5}{|c|}{ BEING FAMILIAR TO CSR } \\
\hline Answers & Frequency & Percent & $\begin{array}{c}\text { Valid } \\
\text { percent }\end{array}$ & $\begin{array}{c}\text { Cumulative } \\
\text { percent }\end{array}$ \\
\hline Not at all & 84 & 19.6 & 19.6 & 19.6 \\
\hline $\begin{array}{l}\text { To a less- } \\
\text { er extent }\end{array}$ & 172 & 40.2 & 40.2 & 59.8 \\
\hline $\begin{array}{l}\text { To some } \\
\text { extent }\end{array}$ & 44 & 10.3 & 10.3 & 70.1 \\
\hline $\begin{array}{l}\text { To a large } \\
\text { extent }\end{array}$ & 112 & 26.2 & 26.2 & 96.3 \\
\hline $\begin{array}{l}\text { To a great } \\
\text { extent }\end{array}$ & 16 & 30.7 & 3.7 & 100.0 \\
\hline Total & 428 & 100.0 & 100.0 & - \\
\hline
\end{tabular}

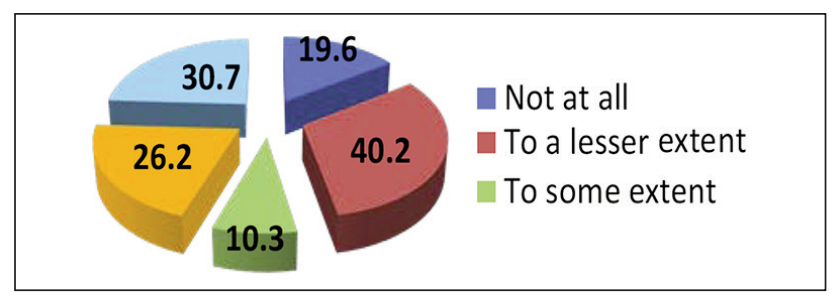

Fig. 1. Being familiar to CSR
Table 2

THE INVOLVEMENT OF ROMANIAN COMPANIES IN CSR

\begin{tabular}{|l|c|c|c|c|}
\hline Answers & Frequency & Percent & $\begin{array}{c}\text { Valid } \\
\text { percent }\end{array}$ & $\begin{array}{c}\text { Cumulative } \\
\text { percent }\end{array}$ \\
\hline Very poor & 32 & 7.5 & 7.5 & 7.5 \\
\hline Poor & 72 & 16.8 & 16.8 & 24.3 \\
\hline None & 172 & 40.2 & 40.2 & 64.5 \\
\hline Strong & 92 & 21.5 & 21.5 & 86.0 \\
\hline $\begin{array}{l}\text { Very } \\
\text { strong }\end{array}$ & 60 & 14.0 & 14.0 & 100.0 \\
\hline Total & 428 & 100.0 & 100.0 & \\
\hline
\end{tabular}

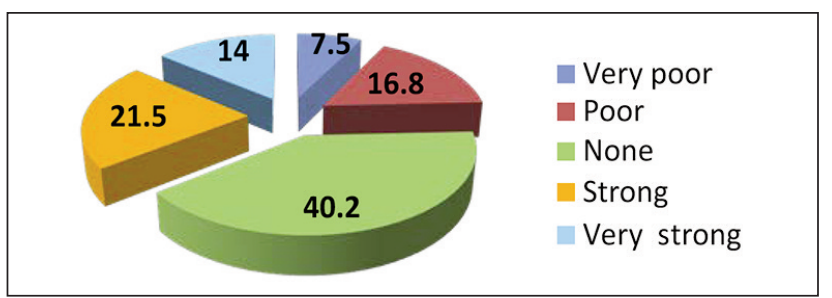

Fig. 2. The involvement of companies in CSR

The respondents' opinions on the involvement of Romanian companies in CSR actions are highlighted in table 2 and figure 2.

It can be noted that most of the respondents, $40.2 \%$ chose the option "None", which means that they have a neutral opinion regarding the involvement of Romanian companies in solving the problems the Romanian society faces. On the second place, by $21.5 \%$ are those who have a "strong" opinion, meaning they are interested in this topic. Summed up, the opinions of those who chose the "Strong" and "Very strong" variants make up $35.5 \%$, surpassing the opinions of those who chose the "Poor" and "Very poor" versions of $24.3 \%$. Therefore, this area is one that is not currently in the area of interest of the population. To the question "What sources did you hear about corporate social responsibility from?", the respondents offered various answers that are highlighted in table 3 and figure 3 . The majority of respondents, $41.1 \%$ found out about this concept from "the Internet", to be more precise, 176 out of 428 persons. It is important to highlight that 38 people have heard about this concept from the questionnaire they filled in. A percentage of $9.3 \%$ respondents heard about this concept from the faculty, and $7.5 \%$ of the respondents have never heard about the CSR concept, at all. The statement "Romanian companies are actively involved in helping the citizens", the highest share is the category "Disagree" with 120 respondents, very close to the "Agree" category, which has got 188 answers. This balance may be the result of the lack of sufficient knowledge of the meaning of the concept CSR by the Romanian population.

Referring to the situation when "Romanian companies are interested in profit and not in citizen welfare", a significant number of respondents, namely 168 


\begin{tabular}{|l|c|c|c|c|}
\hline \multicolumn{5}{|c|}{ SOURCES OF INFORMATION ON CSR } \\
\hline Answers & Frequency & Percent & $\begin{array}{c}\text { Valid } \\
\text { percent }\end{array}$ & $\begin{array}{c}\text { Cumulative } \\
\text { percent }\end{array}$ \\
\hline Television & 84 & 19.6 & 19.6 & 19.6 \\
\hline Internet & 176 & 41.1 & 41.1 & 60.7 \\
\hline Hoardings & 24 & 5.6 & 5.6 & 66.4 \\
\hline Radio & 20 & 4.7 & 4.7 & 71.0 \\
\hline Faculty & 40 & 9.3 & 9.3 & 80.4 \\
\hline $\begin{array}{l}\text { This ques- } \\
\text { tionnaire }\end{array}$ & 36 & 8.4 & 8.4 & 88.8 \\
\hline Others & 16 & 3.7 & 3.7 & 92.5 \\
\hline $\begin{array}{l}\text { Never } \\
\text { heard of }\end{array}$ & 32 & 7.5 & 7.5 & 100.0 \\
\hline Total & 428 & 100.0 & 100.0 & - \\
\hline
\end{tabular}

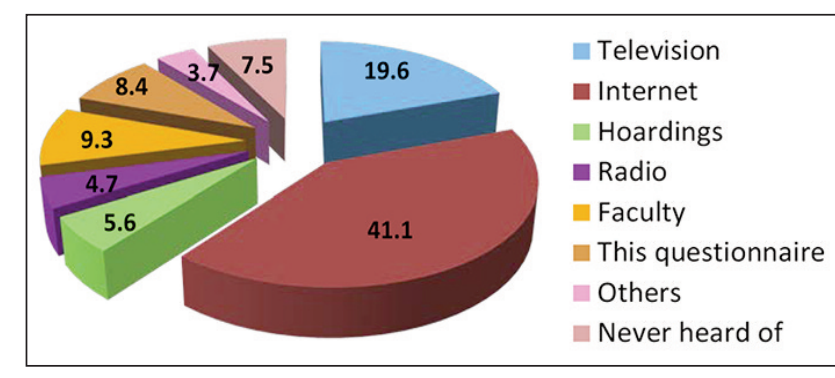

Fig. 3. Sources of information on CSR

to involve in actions of social responsibility and of support for these actions is easily noticeable (table 4). The following responses were given to the question on mentioning the name of a company in the textile industry involved in social responsibility activities, according to the following table (table 5). Thus, the

THE DEGREE OF AGREEMENT OR DISAGREEMENT ON CSR ACTIONS

\begin{tabular}{|l|c|c|c|c|c|}
\hline \multicolumn{1}{|c|}{$\begin{array}{c}\text { The degree of agreement or disagreement } \\
\text { with concern to the following statements }\end{array}$} & $\begin{array}{c}\text { Totally } \\
\text { disagree }\end{array}$ & Disagree & $\begin{array}{c}\text { Neither agree } \\
\text { nor disagree }\end{array}$ & Agree & $\begin{array}{c}\text { Totally } \\
\text { agree }\end{array}$ \\
\hline $\begin{array}{l}\text { Romanian companies are actively involved in helping } \\
\text { citizens }\end{array}$ & 44 & 120 & 44 & 188 & 32 \\
$\begin{array}{l}\text { Romanian companies are interested in profit and not } \\
\text { in citizen welfare }\end{array}$ & 12 & 72 & 48 & 168 & 128 \\
\hline $\begin{array}{l}\text { I think there are more and more companies involved } \\
\text { in social responsibility activities }\end{array}$ & 20 & 144 & 32 & 192 & 40 \\
\hline $\begin{array}{l}\text { Corporate social responsibility is a beneficial aspect } \\
\text { for the society }\end{array}$ & 4 & 12 & 44 & 132 & 236 \\
\hline $\begin{array}{l}\text { I am willing to pay more for a product purchased from a } \\
\text { company that is involved in social responsibility activities }\end{array}$ & 20 & 96 & 40 & 140 & 132 \\
\hline
\end{tabular}

respondents, stated that they agreed with this statement, only 12 people totally disagree with the given assertion.

For the opinion "I consider that there are more and more companies involved in social responsibility activities", 192 persons "Agree", in total contrast being the statement of total disagreement from 20 respondents.

The following statement "Corporate social responsibility is a positive thing for society" gathered the majority of respondents, 236 people for the "Totally agree" answer, which means that the population is aware of the increasing importance of CSR.

For the statement "I am willing to pay more for a product purchased from a company involved in social responsibility activities", the opinions of the interviewees are divided between "Agree" answers from 140 respondents and "Totally agree" with a total of 132 respondents. Thus, people's desire
Table 5

DISTRIBUTION OF COMPANIES IN THE TEXTILE INDUSTRY INVOLVED IN CSR ACTIVITIES IN THE OPINION OF THE CITIZENS

\begin{tabular}{|l|c|c|c|c|}
\hline \multicolumn{1}{|c|}{ Answers } & Frequency & Percent & $\begin{array}{c}\text { Valid } \\
\text { percent }\end{array}$ & $\begin{array}{c}\text { Cumulative } \\
\text { percent }\end{array}$ \\
\hline SC Rifil SA & 64 & 15.0 & 15.0 & 15.0 \\
\hline SC Rosko Textil SRL & 52 & 12.1 & 12.1 & 27.1 \\
\hline SC Moden SRL & 40 & 9.3 & 9.3 & 36.4 \\
\hline SC Benrom SRL & 20 & 4.7 & 4.7 & 41.1 \\
\hline SC Formens SRL & 16 & 3.7 & 3.7 & 44.9 \\
\hline SC Biancospino SRL & 4 & 0.9 & 0.9 & 45.8 \\
\hline SC Pandora Prod SRL & 8 & 1.9 & 1.9 & 47.7 \\
\hline SC Paola Confectii SRL & 12 & 2.8 & 2.8 & 50.5 \\
\hline SC ITS Production SRL & 12 & 2.8 & 2.8 & 53.3 \\
\hline SC Coats Odorhei SRL & 4 & 0.9 & 0.9 & 54.2 \\
\hline SC Coindu Romania SRL & 84 & $1 ., 6$ & 19.6 & 73.8 \\
\hline DC Cottontex SRL & 4 & 0.9 & 0.9 & 74.8 \\
\hline Others & 12 & 2.8 & 2.8 & 77.6 \\
\hline I don't know & 96 & 22.4 & 22.4 & 100.0 \\
\hline Total & 418 & 100.0 & 100.0 & - \\
\hline
\end{tabular}


most well-known company, from the point of view of the citizens, is SC Coindu Romania SRL with $19.6 \%$, followed by SC Rifil SA with $15 \%$, followed by SC Rosko Textil SRL with $12.1 \%$. They are known by citizens as companies that get involved in CSR activities. It can be noticed that $22.4 \%$ of the respondents said that they do not know companies in this industry that are involved in CSR actions.

Similarly, for the statement "Do you think that CSR is well served in the textile industry in our country?", it is to be noticed that $42.1 \%$ of the respondents answered "Neither agree nor disagree", which may mean that they do not have all the information about these actions or that they are not convinced of the seriousness of these actions. At the same time, $24.3 \%$ of the respondents agree with the statement and $14 \%$ are in total agreement with this statement (table 6).

of satisfaction of the population results from the thorough ignorance of the concept and its role in society. At the declarative level, the population agrees to be socially responsible, but to have a minimal to nonexistent involvement, so that the population places responsibility on companies [15].

\section{CONCLUSIONS}

Any economic entity, including those in the textile industry, prior to integrating into its activity social responsibility actions, gets down to a profitability analysis based on financial reporting. Their impact becomes evident in the level of registered expenditures, such as: social expenses, education expenses, expenses for the development of sports, cultural actions, etc. The fundamental orientation is coordinated by the tax mechanisms provided by the tax legislation [16-17]. Thus, the entities are interested in tax facilities they can benefit from in carrying out social responsibility activities, and tax deductions are the tax instrument most commonly used by the national regulator. Yet, the very complex and unstable tax legislation triggers a less-present behaviour of entities on this level. The combination of the patrimonial interests with the charitable actions aimed, in fact, at improving

When asked about the respondents' decision to buy products mainly from some companies in the textile industry that are environmental-friendly and to pay a higher price for them, the questioned respondents answered affirmatively in a very high percentage, more exactly $91.6 \%$, while only $8.4 \%$ say they do not take this aspect into consideration when purchasing textiles (figure 4).

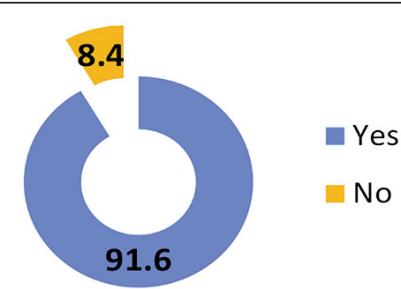

Fig. 4. Consumers' desire to pay a higher price for the environmentally friendly products

Two very important hypotheses have been confirmed, namely, that at most $50 \%$ of Romanians are satisfied with CSR actions organized by the companies in the textile industry in our country, and the hypothesis which claims that at most $50 \%$ of the Romanians are familiar to a little extent to the term CSR. That is why it is possible that this high degree the public image of the entity and, implicitly, at reducing human resource costs [18]. The companies in the textile industry, by tackling with innovative solutions and interest paid to environmental actions, contribute to the sustainable development, a dimension of social responsibility.

If a company does not appeal to consumers, partners, community in the development process, then its profitability and competitiveness will suffer in the long run. CSR aims to ensuring a better connection between the society/community responsibility and the long-term financial objectives of the companies [19]. There are specialists who claim that CSR generates far too high costs in social investments without visible effects, but this concept has to be understood and promoted in terms of long-term benefits without minimizing its strategic role. Communication is an important element of CSR which guarantees transparency for the interested groups. The promoted social programs, however, should not be viewed solely from the perspective of PR and marketing benefits they bring. In setting up the CSR strategy, the companies should start from the community's real needs and afterwards it should define its measurable and honest objectives.

The results of the research are meant to outline the directions of action that companies should introduce 
into their overall business strategy so that the end consumer perceives them as an ally in the sustainable social development. Consumer attitudes and opinions on CSR lead to the need for active visibility for consumer assimilation and understanding.

As a result of the study, it was found only in the reports of the large companies that CSR actions were carried out. In case the small and medium-sized companies have been involved in CSR activities, they are not visible and cannot be known to the general public.

The authors recommend to the managers of the companies a gradual manifestation of the actions regarding the essential values promoted for the improvement of the quality of life and for the optimization of the environmental performance. Similarly, large entities also must be consistent with the observance of the principles of integrated reporting, according to which the transmitted information can be perceived and respond to the needs of consumers.
The limits of the study consist in the inexistence of some reports containing CSR actions undertaken by small and medium-sized companies in Romania. Keeping in mind these limitations, we recommend including CSR actions carried out by small and medium-sized companies in administrators' annual reports.

A future research direction could consist in conducting qualitative research among the managers of companies in Romania in order to study the correlations between the consumers' and managers' opinions on the CSR concept.

The analysis emphasizes the necessity of integrating social responsibility components by the economic entities as an ethical and legal obligation imposed by the general interests of the community for some sustainable development. The attitude of complying with the CSR requirements convinces the community to perceive them as socially responsible societies.

\section{REFERENCES}

[1] The European Way, Corporate social responsibility in the European Union and the fight against poverty: the example of the textile industry in Romania, Available at: https://www.caleaeuropeana.ro/live-video-6-mai-ora-11-00responsabilitatea-sociala-a-intreprinderilor-in-uniunea-europeana-si-combaterea-saraciei-exemplul-industrieitextile-din-romania-in-cadrul-eurosfat-2016/ [Accessed November 7th 2018]

[2] Mohamed, W.S., Arafa, I.M., Investigating corporate social responsibility disclosure by banks from institutional theory perspective, In: Journal of Administrative and Business Studies, 2016, 2, 6, 280-293

[3] CSR Media, Studiu CSR: 35\% dintre companii spun că Responsabilitatea Socială face parte din filosofia firmei, Available at: https://www.csrmedia.ro/studiu-csr-35-dintre-companii-spun-ca-responsabilitatea-sociala-face-partedin-filozofia-firmei/ [Accessed November 9th 2018]

[4] Social Responsibility (Corporate) in Romania, Available at: http://www.csrmedia.ro/wp-content/uploads/2013/ 01/Analiza-Situatiei-RSC-in-Romania-RO1.pdf [Accessed November 9th 2018]

[5] European Commission - Directorate General for Small and Medium Enterprises, Internal Market, Industry, Entrepreneurship and SMEs, Available at: https://ec.europa.eu/info/departments/internal-market-industryentrepreneurship-and-smes_ro [Accessed November 7th 2018]

[6] CSR EMS Forum, Final Report, 2004, Available at: http://www.indianet.nl/EU-MSF_CSR.pdf [Accessed October 22th 2018]

[7] Kotler, P., Lee, N., Coroprate Social Responsibility. Doing the Most Good for your Company and your Cause, In: New Jersey Published by John Wiley \& Sons, 2005, 198-234

[8] lamandi, I.E., Jolde, C.S.R., Corporate social responsibility during the economic crisis. The case of Romanian companies, In: Annals of Faculty of Economics, 2010, 1, 2, 963-969

[9] Filip, R., lamandi, I., Etică și responsabilitate sociala corporativă în afacerile internaționale, In: Bucharest, ASE Publishing, 2008, 134-136

[10] Dewi, N.I.K., Mataram, I.G.A.B., Siwantara, I.W., Validating a framework of the integration of corporate social responsibility and culture: The case of hotel industry, In: International Journal of Business and Economic Affairs, 2017, 2, 1, 31-44

[11] Olaru, M., Stoleriu, G., Sandru, I.M.D., Social Responsibility Concerns of SMEs in Romania, from the Perspective of the Requirements of the EFQM European Excellence Model, In: Amfiteatru Economic, 2011, 13, 29, 57-72

[12] Hassan, R., Exploring the association of corporate social responsibility and employees' organisational citizenship behaviour: A study in Pakistan, In: Journal of Administrative and Business Studies, 2018, 4, 1, 27-40

[13] Anton, C., Consideration related to the attitudes, behaviours and opinions of the managers of the micro, small and mesium entreprises of Brasov, related to the tender of the financial-accounting services companies, In: Proccedings of the International Conference on Business Excellence, 2010, 14-18

[14] Obrad, C., Petcu, D., Ghergheș, V., Suciu, S., Corporate Social Responsibility in Romanian Companies - between Perceptions and Reality, In: Amfiteatru Economic, 2011, 13, 29, 54

[15] Madar, A., Neacşu, N.A., Protection of tabacco consumers and no consumers, In: Proccedings of the International Conference on Business Excellence, 2009, 259-262

[16] Culiuc, E., Mecanisme fiscale de stimulare a filantropiei, In: Chișinău, 2011, Available at: https://www.expertgrup.org/ro/biblioteca/item/332-mecanisme-fiscale-de-stimulare-a-filantropiei [Accessed October 27th 2018]

[17] Bălăşescu, M., Bălăşescu, S., The assertion of consumption goods distribution marketing in retail companies, In: Proccedings of the International Conference on Business Excellence, 2010, 46-48 
[18] Pahayahay, A.B., Asejo, N.R., Pangan, S.M., Dasig Jr., D.D., Panganiban Jr., A.S., A concurrent exploratory study on sectoral engagement model of an altruistic corporate social responsibility in bureau of jail management and penology, In: International Journal of Business and Economic Affairs, 2017, 2, 2, 98-105

[19] Alshannag, F., Basah, M.Y.A., Khairi, K.F., The relationship between corporate social responsibility and corporate financial performance A survey of literature, In: International Journal of Business and Administrative Studies, 2017, 3, 1, 9-15

\section{Authors:}

NICOLETA ANDREEA NEACȘU, SIMONA BĂLĂȘESCU, MARIUS BĂLĂȘESC, CARMEN ELENA ANTON

Transilvania University of Brașov, Faculty of Economics Sciences and Business Administration, Colina Universității no.1, 500084, Brașov, Romania e-mail: f-seaa@unitbv.ro

Corresponding author:

NICOLETA ANDREEA NEACȘU

e-mail: deea_neacsu@yahoo.com 